AGRO-INDUSTRI

Vol. 1 No. 1 ; November 2014

\title{
OPTIMASI PRODUKSI PUPUK KOMPOS TANDAN KOSONG KELAPA SAWIT (TKKS) DAN APLIKASINYA PADA TANAMAN
}

\author{
*JAKA DARMA JAYA ${ }^{1}$, NURYATI $^{1}$, RAMADHANI $^{2}$ \\ ${ }^{1}$ Staff Pengajar Jurusan Teknologi Industri Pertanian, Politeknik Negeri Tanah Laut, Jl. A. Yani, \\ Km 6, Ds. Panggung, kec. Pelaihari, kab Tanah Laut, Kalimantan Selatan \\ ${ }^{2}$ Mahasiswa Jurusan Teknologi Industri Pertanian, Politeknik Negeri Tanah Laut, Jl. A. Yani, \\ Km 6, Ds. Panggung, kec. Pelaihari, kab Tanah Laut, Kalimantan Selatan
}

Naskah diterima : 10 Oktober 2014; Naskah disetujui : 24 November 2014

\begin{abstract}
ABSTRAK
Tandan kosong kelapa sawit (TKKS) merupakan limbah padat yang dihasilkan pabrik kelapa sawit. Pemanfaatan kelapa sawit masih belum optimal dilakukan, oleh karena itu pada penelitian ini dilakukan pemanfaatan TKKS sebagai bahan baku pembuatan kompos. Selain itu, pada penelitian ini juga dilakukan aplikasi pemberian pupuk kompos TKKS pada tanaman cabe dan jagung. Pembuatan pupuk kompos diawali dengan menyiapkan aktivator EM-4 dan mencampurkannya pada bahan berikut: pupuk kandang, dedak, air sumur, air kelapa, dan tandan kosong kelapa sawit (TKKS), diinkubasi pada kondisi aerob. Berdasarkan hasil pengamatan tekstur dan suhu pengomposan, serta hasil pengaplikasian terhadap tanaman cabe dan jagung, diketahui bahwa kompos C dengan komposisi a) Pupuk kandang 0,5 kg, b) Dedak 0,5 kg, c) Air sumur 2 liter, d) Air kelapa 0,1 liter, e) EM-4 0,1 liter, f) TKKS $10 \mathrm{~kg}$ adalah kompos terbaik. Uji sampel terhadap kompos $C$ juga menunjukan bahwa kandungan $P$ total $(0,2725)$ dan $N$ total $(1,30)$ adalah lebih tinggi dari nilai SNI pupuk kompos. Pupuk kompos TKSS bersifat ramah lingkungan bisa menjadi alternatif solusi permasalahan limbah yang ada di perkebunan dan pabrik pengolahan sawit.
\end{abstract}

Kata kunci : Kompos, tandan, sawit, EM-4

\section{PENDAHULUAN}

Proses pengolahan minyak kelapa sawit menghasilkan limbah padat dan limbah cair yang salah satunya berupa tandan kosong kelapa sawit (Mangunsung, 2003). Produksi minyak kelapa sawit kasar Indonesia mencapai 6 juta ton/tahun yang secara bersamaan dihasilkan pula limbah TKKS dengan potensi sekitar 2,5 juta ton per tahun. Dipabrik minyak kelapa sawit, TKKS dulunya hanya dibakar dan sekarang telah dilarang karena adanya kekhawatiran pencemaran lingkungan, sehingga menimbulkan keluhan atau masalah bagi masyarakat.

Salah satu usaha dalam mengatasi hal tersebut adalah dengan memanfaatkan TKKS menjadi pupuk kompos. Saat ini kita telah dapat memanfaatkan TKKS sebagai pengganti pupuk tanaman kelapa sawit yaitu dengan cara menabur langsung TKKS kelapangan, akan tetapi masih ditemukan beberapa permasalahan yang cukup mengganggu seperti tumpukan TKKS dan daya urai yang rendah. TKKS yang terlambat diaplikasikan

\footnotetext{
*Korespondensi :

Telepon/nomor faks : :0512-21537

Email : : jakadj2010@gmail.com
} 
kelapangan berpengaruh terhadap potensi nutrisinya akan berkurang. Disamping itu, TKKS yang membusuk ditempat akan menarik kedatangan jenis kumbang tertentu yang berpotensi merusak pohon kelapa sawit dan mengganggu lingkungan sekitar.

Oleh karena itu pada peelitian ini dilakukan optimasi pengolahan pupuk TKKS sehingga tidak menimbulkan permasalahan di atas. Penggunaan aktivator EM-4 dimaksudkan utnuk mempercepat penguraian dan menjadikan kompos TKKS lebih mudah diserap dan memberikan pengaruh yang baik terhadap pertumbuhan tanaman yang diamati dari pertumbuhan tingg, berat dan jumlah daun pada tanaman.

\section{METODE PENELITIAN}

\section{Alat dan Bahan Penelitian}

Alat yang digunakan pada penelitian ini adalah parang, timbangan, pupuk kandang, dedak, terpal, cangkul, dan ember. Sedangkan bahan yang digunakan adalah tandan kosong kelapa sawit, pupuk kandang, dedak, air kelapa, EM4 dan air sumur. Tandan Kosong Kelapa Sawit yang digunakan dikumpulkan dari lahan perkebunan sawit PT. PN XIII wilayah, Pelaihari Kalimantan Selatan.

\section{Aktivasi EM-4}

Tahapan pertama yang dilakukan ada aktivasi mikroorganisme dengan cara menambahkan 20 ml EM-4 dalam 1 L larutan gula pasir (1 \%). Laruta kemudian diinkubasi selama 24 jam (Bariman, 2009).

\section{Proses Pembuatan Kompos}

Sebanyak $10 \mathrm{Kg}$ TKKS yang telah dicacah dicampurkan dengan $0,5 \mathrm{Kg}$ dedak dan 0,5 Kg pupuk kandang, lalu diaduk sampai homogen. Optimasi pembuatan kompos dilakukan dengan variasi komposisi bahan seperti disajikan pada Tabel 1.

Tabel 1. Komposisi campuran pembuatan kompos

\begin{tabular}{lcccc}
\hline \multicolumn{1}{c}{ Bahan-Bahan } & Kompos A & Kompos B & Kompos C & Kompos D \\
\hline Tandan Kosong (kg) & 10 & 10 & 10 & 10 \\
Dedak (kg) & 0.5 & 0.5 & 0.5 & 0.5 \\
Air Kelapa (Liter) & 0.2 & 0.2 & 0.1 & 0.1 \\
EM-4 (Liter) & 0.2 & 0.1 & 0.1 & 0.2 \\
Air Sumur (Liter) & 2 & 2 & 2 & 2 \\
Pupuk Kandang (Kg) & 0.5 & 0.5 & 0.5 & 0.5 \\
\hline
\end{tabular}


EM-4 yang sudah diaktifkan diambil sebanyak 0,1 ml dan dicampur dengan 2 liter air dan diaduk sampai merata. Larutan EM-4 disiramkan secara perlahan-lahan pada adonan sampai kandungan air pada adonan mencapai kurang lebih 30\% (bila adonan dikepal dengan tangan, air tidak keluar, dan bila kepalan dilepas maka adonan akan pecah). Campuran kompos ditutup rapat dengan terpal dan suhu dipertahankan 40-60 ${ }^{\circ} \mathrm{C}$. Inkubasi dilakukan hingga 15 hari atau sampai kompos terbentuk sempurna ditandai dengan warna coklat kehitam-hitaman, mudah dihancurkan, tidak berbau, dan volume menyusut.

\section{Aplikasi kompos pada tanaman}

Aplikasi dilakukan pada tanaman cabe dan jagung. Bibit tanaman disemai hingga tumbuh kecambah. Lalu dipindahkan pada media tanam yang telah ditambahkan kompos berbeda (Kompos A-D). Pengamatan dilakukan dari hari ke-) hingga hari ke-15. Pengamatn dilakukan pada tiga parameter pertumbuhan yaitu tinggi tanaman, jumlah daun, dan berat tanaman (Rohendi, 2005).

\section{HASIL DAN PEMBAHASAN}

\section{Mikroba dan material campuran pembuatan kompos}

Tahapan pertama yang dilakukan adalah aktivasi EM-4 yang kemudian digunakan sebagai inducer proses penguraian TKKS menjadi kompos. Hal yang perlu diamati sebelum melakukan pembuatan adalah adalah kebersihan alat serta kesuaian takaran. Proses inkubasi atau fermentasi dilakukan selama 24 jam pada tempat yang teduh dengan tujuan mengaktifkan bakteri pelarut yang terkandung dalam EM-4 (Yusuf, 2000).

Tandan kosong kelapa sawit merupakan bahan utama dalam pembuatan kompos. Kandungan yang ada pada tandan kosong tersebut sangat banyak. Dedak berfungsi untuk sumber makanan yang bergizi untuk pertumbuhan mikroba. Pada penelitian ini juga digunakan air kelapa karena tingkat keasaman yang rendah dan merupakan media tumbuh yang baik bagi mikroba. Selain itu, air kelapa juga mengandung gula sehingga lebih mudah dimanfaatkan bakteri. Pupuk kandang merupakan bahan pelengkap tanah yang membantu memperbaikin tektur dan rongga tanah. Penambahan EM-4 dan air kelapa dimaksudkan untuk mempercepat proses fermentasi tandan kosong kelapa sawit (Yusuf, 2000). Pada proses pembuatan kompos, variasi konsentrasi EM-4 dan air kelapa memberikan pengaruh yang sangat besar terhadap proses fermentasi. 


\section{Pengaruh suhu terhadap kecepatan proses fermentasi}

Proses pelapukan dapat diamati dari peningkatan suhu, penurunan volume tumpukan, dan perubahan warna. Kompos yang telah matang ditandai dengan adanya perubahan fisik, yaitu sebagai berikut :

1. Warna TKKS coklat kehitam-hitaman

2. Mudah dihancurkan

3. Tidak berbau

4. Volume menyusut

Kompos yang sudah memiliki ciri-ciri tersebut sudah cukup matang dan siap untuk diaplikasikan ketanaman (Sofian, 2006).

Pengamatan pada hari ke 1-4 menunjukkan terjadinya kenaikan suhu. Ini mengindikasikan bahwa proses fermentasi mulai berlangsung. Pelepasan gas $\mathrm{CO}_{2}$ dan gas lain menyebabkan suhu adonan meningkat. Pengamatan pada hari ke 5-10 menunjukkan penurunan suhu dan mulai konstan pada hari ke 10 dan seterusnya. Penurunan suhu mengindikasikan terjadinya penurunan pelepasan gas pada proses fermentasi. Terlihat dari data bahwa hari ke-10 suhu mulai kontstan, sehingga bisa disimpulkan bahwa proses fermentasi telah berakhir. Profil kenaikan dan penurunan suhu dari 4 (empat) perlakuan fermentasi tersebut menunjukkan perbedaan, dimana kompos $\mathrm{C}$ menunjukkan kenaikan suhu yang lebih tinggi dibandingkan kompos yang lain dan mengalami penurunan pada hari ke-4 (Gambar 1).

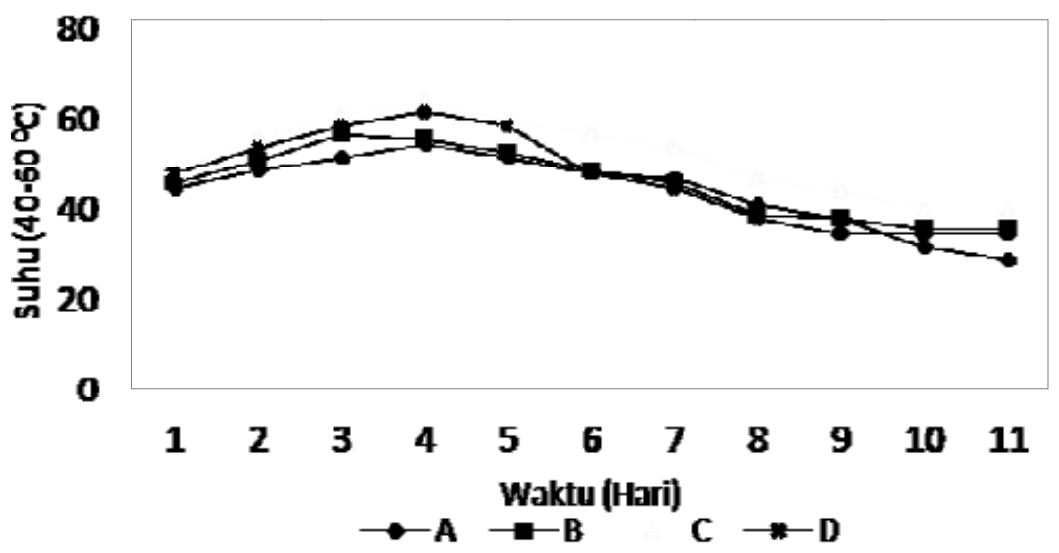

Gambar 1. Grafik hubungan antara suhu dengan waktu fermentasi

Bersamaan dengan proses fermentasi, terjadi juga proses pelapukan dan penguraian tandan kosong menjadi kompos. Hal ini ditandai dengan perubahan fisik tandan kosong kelapa sawit. Berdasarkan pengamatan pada keempat jenis kompos yang dihasilkan dalam proses fermentasi, diketahui bahwa kompos $\mathrm{C}$ mengalami penguraian pada hari ke 7, sedangkan kompos A, B, dan D penguraian terjadi pada hari ke 8. Proses penguraian kompos $\mathrm{C}$ lebih cepat dibandingkan kompos $\mathrm{A}$, B dan D bersesuaian dengan suhu yang 
dihasilkan lebih tinggi, sehingga proses fermentasi berlangsung lebih cepat. Sedangkan kompos $\mathrm{A}, \mathrm{B}$, dan $\mathrm{D}$ proses fermentasi lebih lambat bersesuaian dengan suhu yang dihasilkan tidak terlalu tinggi (Gambar 2).

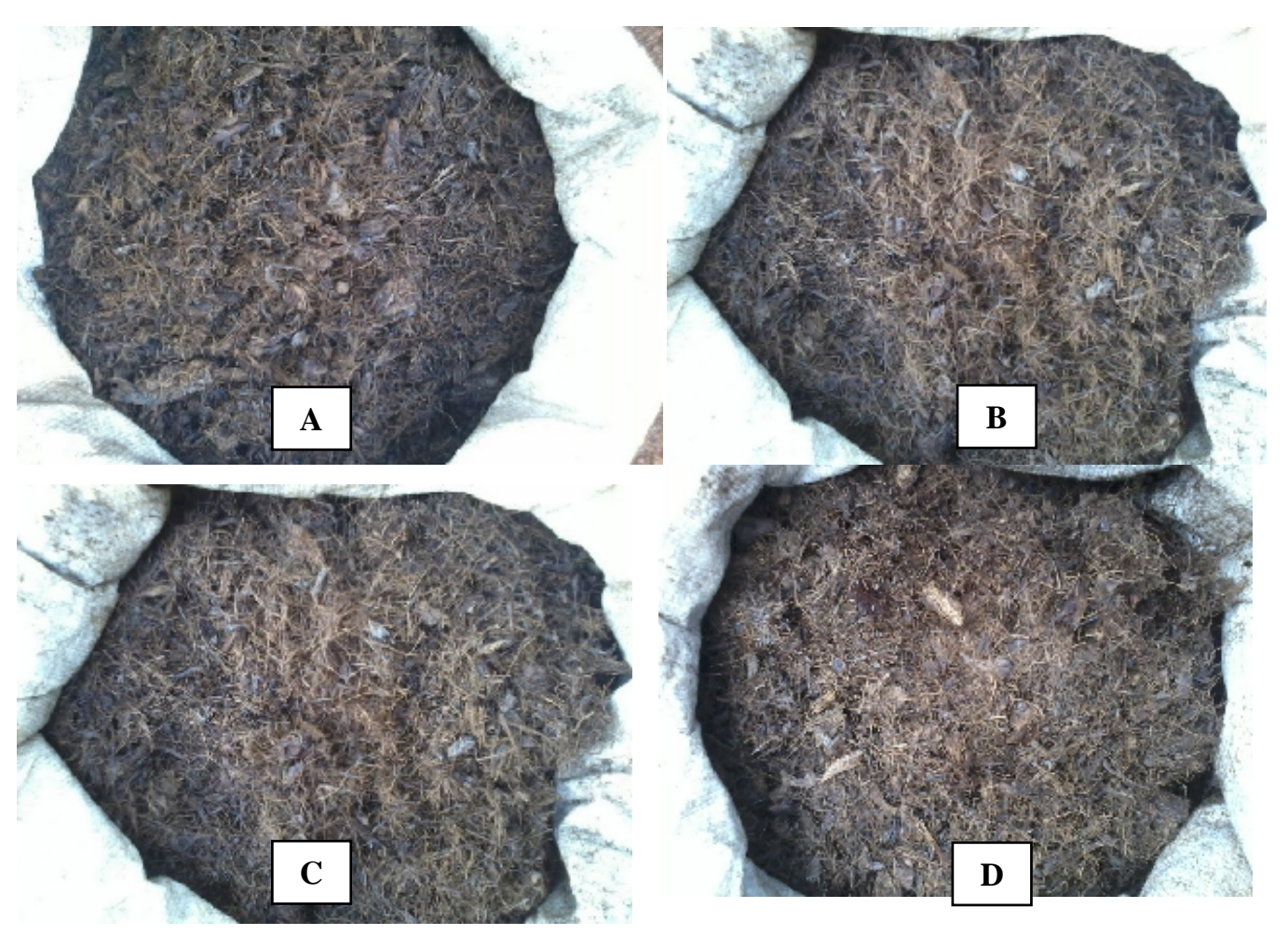

Gambar 2. Penguraian yang terjadi pada kompos A, B, C dan D

Selain pengamatan dan pengukuran kualitatif yang dilakukan dalam engujian kompos di atas, dilakukan juga pengujian kandungan komponen P dan N (Tabel 2).

Tabel 2. Kandungan N dan P kompos C

\begin{tabular}{|c|c|c|c|}
\hline \multirow[b]{2}{*}{ No } & \multirow[b]{2}{*}{ Kode Sampel } & \multicolumn{2}{|c|}{ Parameter } \\
\hline & & $\begin{array}{c}\text { P Total }(\% \\
\left.\mathrm{P}_{2} \mathrm{O}_{5}\right)\end{array}$ & N Total (\%) \\
\hline 1 & Tankos 1 & 0,2949 & 1,59 \\
\hline 2 & Tankos 2 & 0,2103 & 1,1 \\
\hline 3 & Tankos 3 & 0,2941 & 1,18 \\
\hline 4 & Tankos 4 & 0,2908 & 1,31 \\
\hline & Rata-rata & 0,2725 & 1,3 \\
\hline
\end{tabular}

Kompos C yang dihasilkan dari fermentasi TKKS menunjukkan hasil yang baik, karena telah memenuhi dan bahkan melebihi standar kompos SNI 19-7030-2004 tentang 
kandungan $\mathrm{N}$ total $0,40 \%$ dan $\mathrm{P}$ total $0,1 \%$, sedangkan dari hasil pengujian laboraturium terhadap kompos $\mathrm{C}$ menunjukkan bahwa kandungan $\mathrm{N}$ dan $\mathrm{P}$ lebih besar yaitu secara berturut-turu $0,2725 \%$ dan $1,30 \%$. Kompos $\mathrm{C}$ kemudian diaplikan pada tanaman cabe dan jagung.

\section{Aplikasi kompos dari TKKS pada tanaman}

Setelah diketahui kandungan $\mathrm{N}$ dan $\mathrm{P}$ yang dihasilkan, kemudian dilakukan pengaplikasian terhadap tanaman cabe dan jagung agar diketahui kualitas kompos yang dihasilkan. Sebelum dilakukan pengaplikasian terhadap tanaman, pupuk kompos terlebih dahulu dicampur tanah dengan perbandingan pencampuran 1:2 atau 100 gram : 200 gram. Polibag hitam dengan ukuran $1 / 4 \mathrm{~cm}$ digunakan sebagai wadah pertanaman.

\section{Pengaruh penambahan kompos terhadap tinggi tanaman}
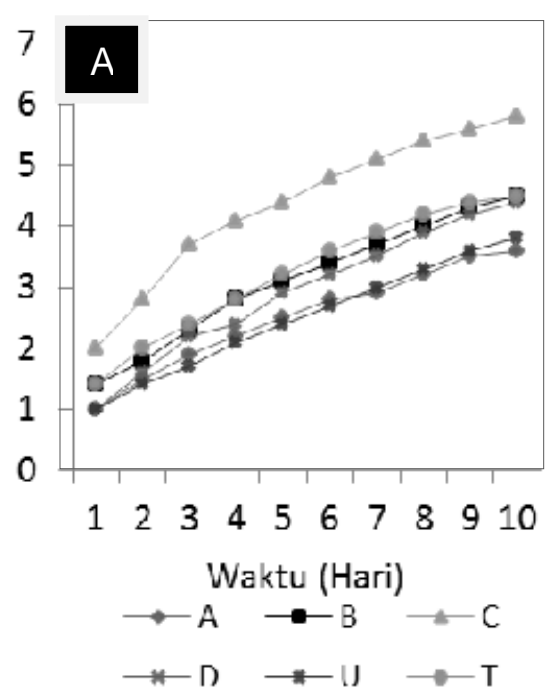

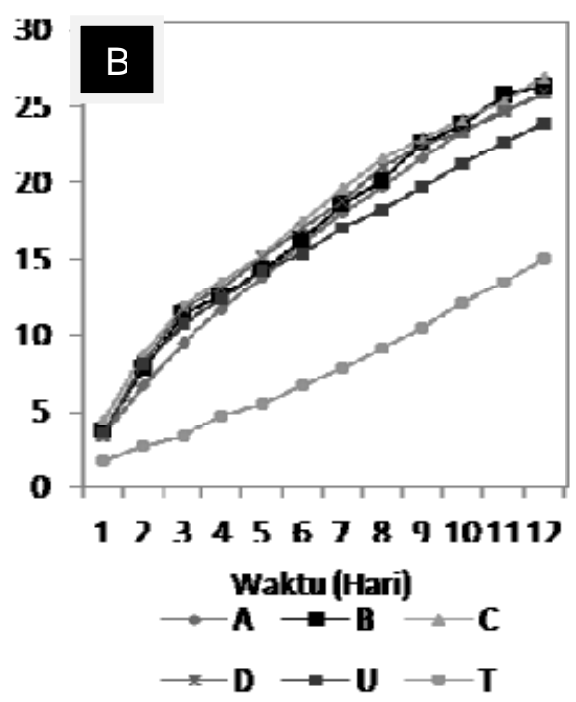

Gambar 3. Pengaruh pemberian kompos TKKS terhadap pertumbuhan tanaman cabe (A) dan jagung (B)

Pengaruh penambahan kompos terhadap jumlah daun

Salah satu indikator pertumbuhan adalah pertumbuhan organ daun. Daun pada tanaman cabe muncul pada hari ke-4 pertanaman. Daun kedua muncul pada hari ke-11. Penambahan daun kedua pada aplikasi menggunakan kompos lebih cepat dibandingkan tanaman yang diaplikasikan dengan pupuk urea (U) dan tanah biasa (T) yang daun keduannya muncul pada hari ke-12 dan hari ke-14. Proses pertumbuhan daun lebih cepat dikarenakan unsur hara yang ada pada pupuk yang digunakan terpenuhi.

Daun pada tanaman jagung yang diaplikasikan dengan kompos TKKS mulai muncul pada pada hari ke 4. Penambahan jumlah daun pada aplikasi dengan kompos 
TKKS terjadi pada hari ke 9 dan hari ke 13. Pada aplikasi dengan urea (U) terjadi penambahan jumlah daun pada hari ke 10 dan 14. Sedangkan pada aplikasi dengan tanah biasa $(\mathrm{T})$ terjadi penambahan jumlah daun pada hari ke 11 dan 15 . Pupuk kompos memberikan hasil yang lebih cepat terhadap penambahan jumlah daun dibandingkan urea dan tanah. Karena unsur hara yang ada pada kompos cukup terpenuhi, sehingga memberikan hasil yang cukup berbeda terhadap penambahan jumlah daun.

\section{Pengaruh penambahan kompos TKKS terhadap berat tanaman}

Penimbangan berat tanaman dilakukan pada seluruh bagian tanaman yang berada di atas tanah. Data berat tanaman yang disajikan pada Tabel 4 menunjukkan bahwa pemberian kompos terhadap tanaman memberikan pengaruh terhadap berat tanaman. Berat tanaman yang ditanam pada media yang diberi pupuk kompos TKKS adalah lebih berat dibandingkan tanaman ditanam pada media tanah biasa dan tanah yang diberi pupuk urea.

Tabel 4. Berat rata-rata tanaman cabe dan jagung

\begin{tabular}{ccc}
\hline \multirow{2}{*}{ Perlakuan } & \multicolumn{2}{c}{ Berat rata-rata tanaman $(\mathrm{g})$} \\
\cline { 2 - 3 } & Cabe & Jagung \\
\hline Kompos & 0,15 & 1,76 \\
Urea & 0,11 & 1,6 \\
Tanah & 0,08 & 1,35 \\
\hline
\end{tabular}

Berdasarkan hasil penelitian antara perlakuan dengan menggunakan kompos secara umum memberikan respon yang baik terhadap pertumbuhan tanaman jagung dan cabe, yang meliputi tinggi batang, jumlah daun, dan berat basah. Hasil pengujian memperlihatkan bahwa antara perlakuan yang menggunakan kompos memberikan hasil yang lebih baik dibandingkan dengan urea dan tanah biasa .

Penggunaan kompos dapat menambah kandungan humus tanah, menaikan jumlah hara tanah yang diambil oleh tanaman, memperbaiki sifat fisik kimia, dan biologi tanah. Dalam hal ini, suatu tanaman akan tumbuh dan mencapai tingkat produksi tinggi apabila unsur hara yang dibutuhkan tanaman berada dalam keadaan cukup tersedia dan berimbang di dalam tanah. Ada tiga unsur hara makro yang mutlak diperlukan oleh tanaman yaitu $\mathrm{N}, \mathrm{P}, \mathrm{K}$, apabila salah satu unsur tersebut tidak tersedia didalam tanah, akan mempengaruhi pertumbuhan dan produksi tanaman (Soegiman, 1982).

Perbedaan pertumbuhan yang nyata antara menggunakan pupuk kompos tandan kosong kelapa sawit, urea, dan tanpa menggunakan kompos. Karena kompos merupakan 
pupuk yang lengkap dan dapat memperbaiki semua sifat-sifat tanah (Sutedjo, 1992). Adanya EM-4 sebagai elemen dalam pembuatan kompos, sangat bermanfaat untuk meningkatkan kesuburan tanah, baik fisik, kimia, dan biologi tanah, sehingga dapat meningkatkan pertumbuhan dan perkembangan tanaman serta meningkatkan produktivitas tanah dan tanaman (Wididana dan Higa, 1993).

Berdasarkan hasil pengamatan pada tekstur dan suhu pengomposan, serta hasil aplikasi terhadap tanaman cabe dan jagung, diketahui bahwa kompos C dengan komposisi a) Pupuk kandang 0,5 kg, b) Dedak 0,5 kg, c) Air sumur 2 liter, d) Air kelapa 0,1 liter, e) EM-4 0,1 liter, f) TKKS $10 \mathrm{~kg}$ adalah kompos terbaik. Uji sampel terhadap kompos $\mathrm{C}$ juga menunjukan bahwa kandungan $\mathrm{P}$ total $(0,2725)$ dan $\mathrm{N}$ total $(1,30)$ adalah lebih tinggi dari nilai SNI pupuk kompos. Hal ini menunjukkan bahwa pupuk kompos TKSS bersifat ramah lingkungan dan bisa menjadi alternatif solusi permasalahan limbah yang ada di perkebunan dan pabrik pengolahan sawit.

\section{UCAPAN TERIMAKASIH}

Terima kasih disampikan kepada Politeknik Negeri Tanah Laut atas bantuan fasilitas, materil dan non materil dalam pelaksanaaan penelitian ini.

\section{DAFTAR PUSTAKA}

Bariman, SP. 2009. Teknik Pembuatan Pupuk Organik. Badan penelitian dan pengembangan pertanian, Depertemen Pertanian.

Mangunsung. 2003. Buku Ajar Teknologi Pengolahan Kelapa Sawit. Polnep. Pontianak.

Rohendi, E. 2005. Lokakarya Sehari Pengolahan Sampah Pasar DKI Jakarta, Sebuah Prosiding. Bogor, 17 Februari 2005.

Soegiman, 1982. Ilmu Tanah, Air dan Jaringan Tanaman. PT Rineka Cipta Jakarta.

Sofian. 2006. Sukses Membuat Kompos dari Sampah. Agromedia Pustaka

Wididana, G.M. dan T. Higa, 1993. Penuntun Bercocok Tanam Padi dengan Teknologi Effective Micro-organism-4. Songgolangit Persada, Jakarta.

Yusuf, M. 2000. Manfaat EM-4 Pada Tumbukan Daerah Tropis. Jakarta. 